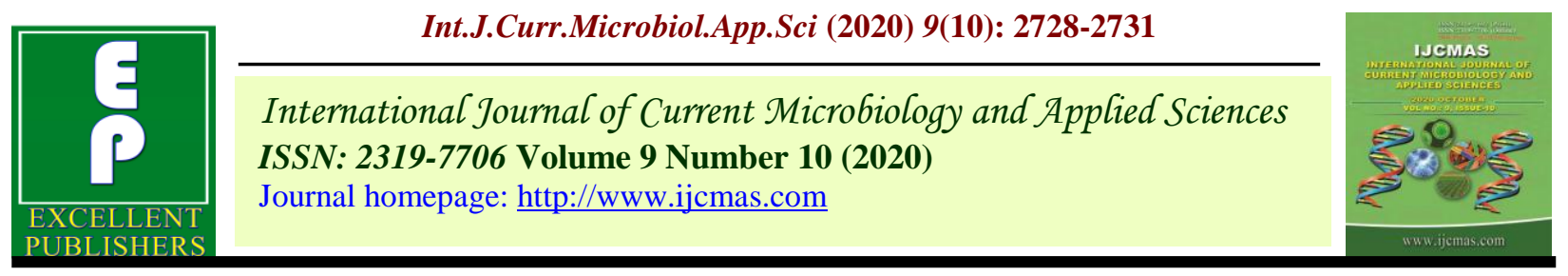

Original Research Article

https://doi.org/10.20546/ijcmas.2020.910.329

\title{
Response of Fertilizer Nitrogen and Potassium on Yield Maximization of Sesame
}

\author{
S. Gobika ${ }^{1 *}$, E. Subramanian ${ }^{1}$, A. Gurusamy ${ }^{1}$ and P. Kannan ${ }^{2}$ \\ ${ }^{1}$ Department of Agronomy, ${ }^{2}$ Department of Soils and Environment, Agricultural College and \\ Research Institute, TNAU, Madurai, India \\ *Corresponding author
}

\section{A B S T R A C T}

\begin{tabular}{l} 
K e y w o r d s \\
$\begin{array}{l}\text { Nitrogen, } \\
\text { Potassium, Split } \\
\text { application, Sesame }\end{array}$ \\
\hline Article Info \\
$\begin{array}{l}\text { Accepted: } \\
\text { 20 September } 2020 \\
\text { Available Online: } \\
\text { 10 October } 2020\end{array}$ \\
\hline
\end{tabular}

\section{Introduction}

Among the oilseeds, sesame is the most important vegetable oilseed crop with diversified uses for mankind. Its edible oil content and protein content ranges between 46-52 per cent and 18-20 per cent respectively. It is generally known as "Poor man's substitute for ghee" and the seed contains carbohydrate, fats, fiber, vitamins, minerals and all the essential amino acids. Presence of antioxidants mainly lignins such as sesamolin, sesamol, sesaminol and sesamin provides the longer shelf life. It occupies 44.61thousand ha of cultivable area with the production and productivity of 24.45 thousand tonnes and $548 \mathrm{~kg} \mathrm{ha}^{-1}$ respectively (Ministry of Agriculture and Farmer's Welfare, Govt. of India (2018-19). Though the productivity has been gradually increasing, it is $25 \%$ lesser to the average productivity of the world. The huge yield gap and farm losses are the reasons behind the lesser net gain of the sesame producers. The yield gap can be reduced by the adopting the newer technologies with better nutrient management practices. This calls to optimize the fertilizer nutrient with major concern on macro nutrients in sesame. Sesame is highly fertilizer responsive especially to nitrogen. Nitrogen increases the metabolic process and the potassium enhances the activity of the 
enzymes as major role in augmenting the quality and seed yield of the crop. Gebregergis (2019) suggested that N fertilizers should be applied in two to three times (splits) and not to be applied as basal. Hence sesame is a highly nutritive feeder, the split application of nutrients may increase the nitrogen use efficiency and balances the soil reserve pool. Keeping these facts to overcome the above constraints, the study on the effect of fertilizer nutrient on the yield of sesame has been undertaken.

\section{Materials and Methods}

The field trail was conducted during kharif'(2019) at Agricultural College and Research Institute, TNAU, Madurai which falls under the southern plateau and hill region of agro climatic zone of India in the latitude of $9^{0} 54^{\prime} \mathrm{N}$ and longitude of $78^{0} 54^{\prime} \mathrm{E}$ and the elevation of $147 \mathrm{~m}$ above Mean Sea Level. The sub tropical climatic condition prevails and the weather conditions during the cropping period are depicted in Figure 1.

The experiment was laid out in the factorial randomized block design with nutrient level and spilt application of nitrogen and potassium. The treatments are $\mathrm{M}_{1}-75 \% \mathrm{RDF}$ of $\mathrm{N}$ and $\mathrm{K}, \mathrm{M}_{2^{-}} 100 \% \mathrm{RDF}$ of $\mathrm{N}$ and $\mathrm{K}, \mathrm{M}_{3^{-}}$ $125 \%$ RDF of $\mathrm{N}$ and $\mathrm{K}$ and $\mathrm{M}_{4}-\mathrm{STCR}$ based $\mathrm{N}$ and $\mathrm{K}$ nutrient management, $\mathrm{S}_{1^{-}} 100 \%$ RDF as basal, $\mathrm{S}_{2^{-}} 50 \%$ as basal and $50 \%$ at 15 DAS, $\mathrm{S}_{3-}-50 \%$ as basal, $25 \%$ at 15 DAS, $25 \%$ at $30 \mathrm{DAS}$ and $\mathrm{S}_{4^{-}} 25 \%$ as basal, $50 \%$ at 15 DAS, $25 \%$ at 30 DAS. TMV 7 was used as test variety at the spacing of $30 \times 30 \mathrm{~cm}$. The fertilizer (NPK) recommendation of irrigated sesame 35:23:23 kg ha ${ }^{-1}$. The full dose of phosphorous was applied as basal. The nitrogen and potassium application was applied as per the treatments. The plant protection measures were taken based on the necessity. The crop was harvested at 85 DAS and post harvest processes were carried out.
The parameters studied are plant height, number of branches, seed and oil yield. The collected data were subjected to the Fisher's method of ANOVA technique and results were discussed.

\section{Results and Discussion}

Fertilizer level on growth and yield of sesame

An appraisal of data in table resulted that plant height, number of braches had significant increase in nutrient level. The higher values were observed in $125 \%$ RDF of nitrogen and potassium which is in statistically similar with $100 \%$ RDF of nitrogen and potassium. The nitrogen promoted the meristematic activity of the cells and also enhances the photosynthetic efficiency and also increasing level of potassium ensures the availability of potassium in soil plant root system enhanced the plant metabolic activity (Kale et al., 2019). The seed and oil yield has been linearly enhanced with an increasing nutrient levels. The higher seed $\left(845.60 \mathrm{~kg} \mathrm{ha}^{-1}\right)$ and oil yield $\left(415.99 \mathrm{~kg} \mathrm{ha}^{-1}\right)$ were recorded in $125 \%$ RDF of nitrogen and potassium. It also produced the higher seed oil content (49.0\%). This may be due to the increase in nutrient content may boosted the vegetative and reproductive growth for achieving the potential yield. The results were supported by the findings of Jadav et al., (2010), Shilpi et al., (2012) Jamdhade et al., (2017).

\section{Split application of nitrogen and potassium on growth and yield of sesame}

A perusal of data indicates that split application of nitrogen and potassium had an influence on growth parameters viz., plant height and number of branches, seed yield, oil content and oil yield. The taller plants (131.59 $\mathrm{cm})$ and more number of branches (10.44) 
were found in $50 \%$ as basal, $25 \%$ at 15 DAS, $25 \%$ at 30 DAS and full dose as basal application showed the reduced growth. This proves that the split application engaged in promotion of the vegetative growth. The split application increased the yield by $1.23 \%$ over the basal application.

Table.1 Nutrient level and split application of $\mathrm{N}$ and $\mathrm{K}$ on growth, yield and quality of sesame

\begin{tabular}{|c|c|c|c|c|c|}
\hline Treatments & $\begin{array}{l}\text { Plant height at } \\
75 \text { DAS }(\mathrm{cm})\end{array}$ & $\begin{array}{l}\text { No. of branches } \\
\text { at } 75 \text { DAS }\end{array}$ & $\begin{array}{c}\text { Seed yield } \\
\left(\mathrm{kg} \mathrm{ha}^{-1}\right)\end{array}$ & $\begin{array}{l}\text { Oil content } \\
(\%)\end{array}$ & $\begin{array}{l}\text { Oil yield } \\
\left(\mathrm{kg} \mathrm{ha}^{-1}\right)\end{array}$ \\
\hline \multicolumn{6}{|c|}{ Factor 1: Fertilizer dosage } \\
\hline $\mathbf{M}_{1}$ & 121.35 & 8.47 & 713 & 47.83 & 341 \\
\hline $\mathbf{M}_{2}$ & 128.85 & 9.24 & 783 & 48.91 & 385 \\
\hline $\mathbf{M}_{3}$ & 130.07 & 10.11 & 846 & 49.00 & 416 \\
\hline $\mathbf{M}_{4}$ & 119.49 & 8.43 & 687 & 48.00 & 332 \\
\hline S.Ed & 2.72 & $\mathbf{0 . 3 3}$ & 14.92 & 0.42 & 8.06 \\
\hline $\mathrm{CD}(\mathrm{p}=\mathbf{0 . 0 5})$ & 5.51 & 0.67 & 30.44 & 0.85 & 16.49 \\
\hline \multicolumn{6}{|c|}{ Factor 2 : Split application of $\mathrm{N}$ and $\mathrm{K}$} \\
\hline$S_{1}$ & 117.37 & 7.32 & 673 & 47.40 & 323 \\
\hline $\mathbf{S}_{2}$ & 124.76 & 9.32 & 704 & 48.00 & 341 \\
\hline $\mathbf{S}_{\mathbf{3}}$ & 131.59 & 10.44 & 832 & 49.40 & 412 \\
\hline $\mathbf{S}_{4}$ & 126.03 & 9.17 & 819 & 49.00 & 401 \\
\hline S.Ed & 2.72 & 0.33 & 14.92 & 0.42 & 8.06 \\
\hline $\mathrm{CD}(\mathrm{p}=0.05)$ & 5.51 & 0.67 & 30.44 & 0.85 & 16.49 \\
\hline
\end{tabular}

Fig.1 Weather data during the cropping period of sesame

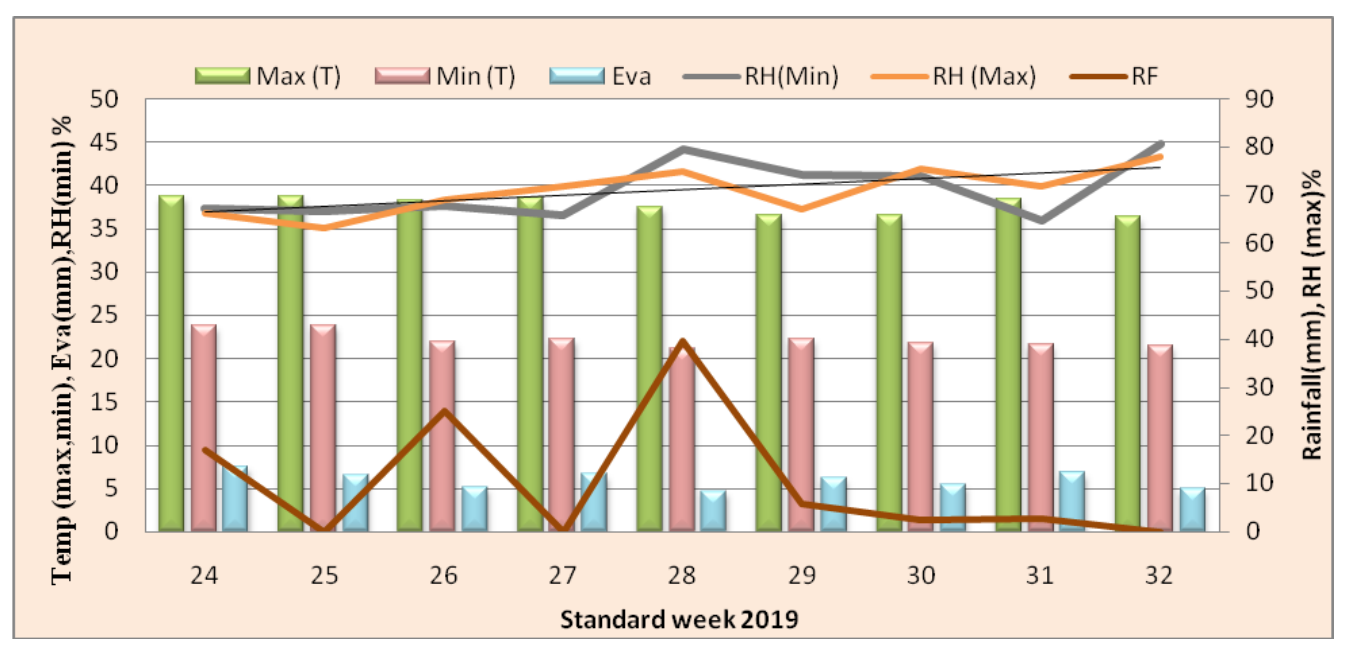

The higher oil content (49.40\%) and oil yield $\left(412.80 \mathrm{~kg} \mathrm{ha}^{-1}\right)$ were noticed in $50 \%$ as basal, $25 \%$ at 15 DAS, $25 \%$ at 30 DAS and it is close enough to treatment $25 \%$ as basal, $50 \%$ at $15 \mathrm{DAS}, 25 \%$ at $30 \mathrm{DAS}$. Dos santos et al.,
(2018) documented that growth and yield were positively influenced by the timing of fertilizer application. The split application boosted the $\mathrm{N}$ content in leaves, seed yield and oil content in sesame. The literature 
studies showed similarity in results with Kalaiselvan and Balasubramanian (2002).

In conclusion the study concluded the optimum dose and split application of nitrogen and potassium enhanced the sesame yield in the study area. The split application improves the source to sink assimilation and also reduces the overloading of chemical fertilizers in the soil reserve pool by the increased nitrogen use efficiency. Hence, $150 \%$ RDF and split application of nitrogen and potassium as $50 \%$ at basal, $25 \%$ at 15 DAS, $25 \%$ at 30 DAS were adequate for the optimum performance of sesame and also makes a positive impact on the economics of the farmers.

\section{References}

Dos Santos, M. G., Ribeiro, R. M. P., de Albuquerque, J. R. T., Lins, H. A., Júnior, A. P. B., Neto, F. B.,. .. \& de Souza, A. R. E. (2018). Production performance of sesame cultivars under different nitrogen rates in two crops in the Brazilian semi-arid region. Industrial Crops and Products, 124, 1-8.

Jadav, D. P., Padamani, D. R., Polara, K. B., Parmar, K. B., \& Babaria, N. B. (2010). Interaction effect of sulphur and potassium on yield and nutrients uptake by sesame (Sesamum indicum
L.). Asian Journal of Soil Science, 5(1), 144-147.

Jamdhade, K., Chorey, A., Tijare, B., \& Bhale, V. M. (2017). Influence of Irrigation Regimes and Nitrogen Levels on Growth, Yield and Economics of Summer Sesame. Int. J. Curr. Microbiol. App. Sci, 6(3), 23892393.

Kalaiselvan, P., Subrahmaniyan, K., \& Balasubramanian, T. N. (2002). Effect of split application of $\mathrm{n}$ and $\mathrm{k}$ on the growth, yield attributes and yield of sesame. Sesame and Safflower Newsletter, (17), 62-65.

Kale, P. D., Thaokar, A., Gawali, K. A., \& Jatav, S. K. (2019). Response of sesame (Sasamum indicum L.) to nitrogen and potassium fertilization. Journal of Pharmacognosy and Phytochemistry, 8(6), 411-414.

Shilpi, S., Islam, M. N., Sutradhar, G. N. C., Husna, A., \& Akter, F. (2012). Effect of Nitrogen and Sulfur on the Growth and Yield of Sesame. International Journal of Bio-resource and Stress Management, 3(2), 177-182.

Zenawi, G., \& Mizan, A. (2019). Effect of Nitrogen Fertilization on the Growth and Seed Yield of Sesame (Sesamum indicum L.). International Journal of Agronomy, 2019.

\section{How to cite this article:}

Gobika, S., E. Subramanian, A. Gurusamy and Kannan, P. 2020. Response of Fertilizer Nitrogen and Potassium on Yield Maximization of Sesame. Int.J.Curr.Microbiol.App.Sci. 9(10): 2728-2731. doi: https://doi.org/10.20546/ijcmas.2020.910.329 